I. V. Kryvorotko, A. V. Chykin, M. Ye. Tymchenko,

S. O. Beresnyev,

T. Z. Alexandrov

State Institution «Zaitsev V. T. Institute of General and Urgent Surgery of the National Academy of Medical Scincese of Ukraine»

\section{SURGICAL TREATMENT OF PATIENTS WITH EXTRAORGANIC TUMORS OF THE PELVIC LOCALIZATION WITH INVASION OF THE ILIAC VESSELS}

Abstract. The aim of our study was to determine the indications for expanding the scope of operations in patients with pelvic extraorgan local formations.

Materials and methods. The results of surgical treatment of 7 patients with non-organ tumors of the pelvic localization, who underwent resection on the main vessels in connection with their involvement in the tumor process, are presented.

Results and discussion. A total of 7 interventions were performed on the iliac arteries -2 resections with an end-to-end anastomosis and 5 prostheses (one case - the aorta resection with reconstruction with a bifurcation prosthesis).

Patients with pelvic extraorgan tumors are a special cohort of patients, due to the presence of several organs in a narrow space, which inevitably causes them to fit snugly to the tumor. Locally advanced tumor process in extraorganic tumors involving the main vessels of the pelvis and adjacent organs is not a reason to refuse surgery, and despite the complications, repeated recurrences and previous operations, are well tolerated by patients. This is especially important due to the lack of a real alternative to surgical treatment of this group of patients.

Conclusions. Surgical intervention in the treatment of pelvic inorganic tumors involving the main vessels is the only radical method of treatment. Invasion of the main arterial and venous vessels is not a contraindication to surgery in patients with pelvic tumors. Combined angioplastic interventions allow to achieve a long without recurrent period even after cytoreductive operations.

Key words: extraorgan pelvic tumors, vessels, surgical treatment.

\section{Introduction}

Tumors that are localized in the extraperitoneal space, between the peritoneal leaf of the mesentery, subperitoneally in the pelvic cavity and have no organ affiliation, are combined into the concept of extraorganic extraperitoneal tumors $[1,2]$. It is believed that the first description of extraorganic extraperitoneal tumors was given by Benivieni in 1507, and in 1829 Lobstein proposed the term «extraperitoneal sarcoma». In the next century, there were many scientific publications on the problem of extraorganic peritoneal tumors. Unfortunately, most of them are based on a few clinical observations or are a description of individual clinical cases [1-4].

A number of foreign authors generally consider extraorganic peritoneal tumors in a single complex with soft tissue neoplasms, based only on their histogenesis, not taking into account the localization, namely the latter largely determines the specificity of diagnostic and therapeutic tactics [4]. This fact is mainly due to the rarity of this pathology, according to various authors, extraorganic peritoneal tumors account for 0.03 to $1.0 \%$ of all human tumors [3-6].
Extraorganic peritoneal tumors are extremely diverse in their morphological structure of the group of tumors [4]. Inorganic neoplasms of pelvic localization are difficult in terms of diagnosis and treatment. This is due to the following circumstances: topographic and anatomical relationships of pelvic tumors are such that they are close to the structures of the extraperitoneal space (iliac arteries and veins, ureters, nerves) and pelvic organs (rectum, uterus, bladder, prostate), often becomes the cause of their invasion; the rigid bone structure of the pelvis limits the possibilities of operative access and the convenience of manipulation in this area $[4,6]$.

Such patients, not infrequently, are denied surgical treatment due to the technical complexity of surgery and, as is commonly believed, deliberately palliative in nature; the effectiveness of radiation therapy and chemotherapy for pelvic extraorgan tumors is quite modest, in this regard, the main role is played by the surgical method. The desire of surgeons to preserve the tumor-affected vessel at all costs, often leaving a tumor infiltration on its wall, which significantly increases the risk of recurrence of the disease, should be considered erroneous. 
Oncological adequacy of surgery requires monoblock removal of the tumor-affected organ and resection of the blood vessel, followed by its reconstruction [7]. It should be recognized that the performance of operations related to resection, as well as one or another type of vascular plasticity in pelvic extraorgan tumors, can only afford large, technically equipped surgical centers with qualified surgical personnel [6]. This provision is explained as follows: the surgical team must be morally and technically ready for such operations, because not always at the stage of preoperative examination can reliably detect and confirm tumor invasion of the main vessel; removal of pelvic tumors is often accompanied by massive blood loss and requires the coordinated work of anesthesiologists, resuscitators and blood transfusion services; the operating room must be equipped with modern types of vascular suture material, synthetic prostheses and surgical instruments; combined interventions should be performed by highly professional oncosurgeons trained in vascular surgery or joint teams of abdominal and vascular surgeons.

In the literature there are isolated publications on vascular plasticity in the removal of extraperitoneal tumors. Some of them suggest that the removal of extraorganic tumors together with the vessel involved in the tumor process not only increases the radicality of the intervention, but also improves the quality of life and long-term results [8]. In favor of extended combined interventions with vascular resection is the fact that patients who have undergone even palliative resection of main vessels, live significantly longer than patients who have undergone non-radical or cytoreductive surgery without vascular resection [9].

Currently, based on the fact that there is no alternative to surgical treatment for pelvic extraorgan tumors, the role of preoperative diagnostic methods in assessing the prevalence of the tumor process and the involvement of blood vessels $[6,9]$. The access of choice for pelvic extraorgan tumors is through peritoneal, because midline laparotomy allows a complete revision of the abdomen and pelvis, assess the location of the tumor and its relationship with surrounding structures, provide access to the main vessels, visual inspection of the anterior organs and create adequate zone [10].

Based on the considerations of radicalism, it is optimal to extracapsular allocation of the tumor as a single block with the surrounding tissue and organs involved in the process. Only in this way [9-11] it is possible to adhere to the principle of ablasticity.

\section{The aim of study}

To determine the indications for expanding the scope of operations in patients with pelvic extraorgan local formations.

\section{Materials and methods}

The results of surgical treatment of 7 patients with non-organ tumors of the pelvic localization, who underwent resection on the main vessels in connection with their involvement in the tumor process, are presented. In all patients, the tumor was mainly located in the pelvic cavity, thus, the tumors were attributed by us to pelvic extraorganic tumors. In the treatment of patients, we were guided by data depending on preoperative diagnosis and intraoperative data.

The group of patients included 3 men and 4 women aged 26 to 75 years (mean age 54 years). Among the histological forms of the tumor, liposarcomas predominated -4 observations (including tumors with a high degree of differentiation, $\mathrm{G} 1-2$ cases and with a low degree of differentiation, G3 2 cases), leiomyosarcomas - 2 observations (G1/G3 - 1 case) and 1 case шванноми.

Surgical interventions in a radical volume were performed in 4 patients, in 3 cases the reason for the non-radical nature of the operation was the growth of the tumor in the bone structures (pelvic walls, spine). Recurrent tumors occurred in 4 cases. The size of the tumor ranged from 10 to $50 \mathrm{~cm}$ in diameter. Two patients underwent exploratory laparotomies before hospitalization in other clinics (tumors were recognized as unresectable due to vascular invasion), and one patient underwent chemotherapy. One patient underwent resection and plastic surgery of the left external iliac artery with an end-to-end anastomosis during the first operation. In case of tumor recurrence involving the aorta after 2 years, we performed a second operation with resection of the abdominal aorta (below the renal vessels) and external iliac arteries with prosthetics.

The introduction of an aggressive surgical approach into our practice was helped by the use of personal experience of angioplasty in this group of patients and the analysis of data from the world literature.

\section{Results and discussion}

A total of 7 interventions were performed on the iliac arteries -2 resections with an end-toend anastomosis and 5 prostheses, one bottom on the aorta - resection with reconstruction with a bifurcation prosthesis. The spread of the tumor to neighboring organs occurred in 5 patients. In one patient with extraorganic leiomyosarcoma involving the right common iliac vessels, metastases in the left lobe of the liver were detected before the operation, in connection with which the first stage was performed extended left hemihepatectomy, and a month later the second stage - tumor removal with vascular resection and prosthetics. Thus, the main proportion of patients at the time of surgery had a pronounced locally advanced tumor process in the 
abdominal cavity with the involvement of neighboring organs and main vessels. Reconstruction of the resected artery on an end-to-end basis was performed using Prolen 4/0 suture material. Prosthetics of external iliac arteries was performed with a vascular prosthesis PTFE company Gortex, aorta - bifurcated corrugated prosthesis of the same company. Before stopping the blood flow, all patients were administered unfractionated heparin at a dose of 5,000 IU. In the event of massive intraoperative bleeding, autoinfusion of own erythrocytes was used to restore blood loss. Intraoperative blood loss averaged 2,600 $\mathrm{ml}$ (300 to 4,200 $\mathrm{ml}$ ), due to the development of a rich network of extraperitoneal blood vessels, as well as a network of venous collaterals and their forced damage during mobilization.

Operations without resection of adjacent organs were performed in two patients with primary tumors, and one of them in the event of subsequent recurrence performed a combined operation. Among the removed organs were kidneys - in 2 cases, adrenal gland - in 1 case, uterine appendages - in 2 cases, colon - in 1 case, appendix - In 2 cases, and in 2 cases ureteral resection was performed, with one of them, without a primary anastomosis, with the formation of an external nephrostomy. Patients with pelvic extraorganic tumors are a special cohort of patients: the presence of several organs in a narrow space inevitably causes at least a close fit to the tumor, even with the small size of the latter. Expansion of the surgical reception and excision of the tumor with its bed and adjacent tissues means in practice a mutilated operation with the removal of several organs. On the other hand, evisceration of the pelvic organs is an unacceptable tactic in all patients. Removal of the tumor leaving the capsule is a safe method of surgery, however, almost always inevitably leads to recurrence of the disease.

Coupling-like coverage of the main vessels by the tumor usually means either a direct invasion of the vessel wall, or the involvement of the adventitia. In our opinion, the involvement of the vessel by more than $50 \%$ of the semicircle detected by CT, or obvious signs of ingrowth in direct angiography should be considered as a direct indication for angioplasty. In most patients, we did not encounter severe atherosclerosis of the aorta and iliac vessels, in connection with which the conditions for the vascular suture were quite favorable. All patients were operated with median laparotomy access. The final assessment of the local prevalence of the tumor process and its resectability was carried out only with the maximum possible tumor mobilization. At the same time access to extraperitoneally located tumor nodes began with mobilization of a large intestine on the right or left flank with preservation if possible of vessels feeding a gut. It was also mandatory to isolate large main vessels above and below the segment involved in the tumor and control them with turn- stiles. An important stage in the mobilization of the structures of the extraperitoneal space was the control of the ureters and nerve trunks - in particular the femoral nerve. The ureter on the affected side, if possible, was catheterized before surgery. Despite all the possibilities of preoperative diagnosis, the final scope of the operation became clear only during the intervention. There were no fatalities in the immediate postoperative period (within 30 days after surgery). The postoperative period occurred in 3 patients without complications, 1 of them after the combined intervention. In addition, in one case after surgery there were the following complications: pleurisy, paresis of the lower extremity on the right, intestinal paresis.

Thus, the leading complications of the postoperative period were impaired motor function of the lower extremity and perforation of the hollow organ. All these complications occurred in patients with non-radical volumes of operations due to the growth of the tumor in the bone structures. Apparently, the complications are associated with the need for surgery in a locally advanced tumor process and forced injury of the femoral nerve. Neurotropic therapy in most cases minimizes the consequences of injury to large nerves. Extended mobilization of the colon is associated with changes in blood circulation and microcirculation in this area, which in one case led to perforation of the colon.

Locally advanced tumor process in extraorganic tumors involving the main vessels of the pelvis and adjacent organs is not a reason to refuse surgery, and despite the complications, repeated recurrences and previous operations, are well tolerated by patients. This is especially important due to the lack of a real alternative to surgical treatment of this group of patients.

All operated patients were followed in the long term. Two patients died from disease progression within 20 months after non-radical surgery (leiomyosarcoma G1) and 18 months after radical resection (leiomyosarcoma G3). Three patients survived radical surgery: no progression for 34 and 9 months after removal of liposarcoma (G3) and benign schwannoma, respectively. One patient was alive for 33 months after liposarcoma (G1) removal with recurrence in the aortic bifurcation and inferior vena cava confluence, with recurrence occurring 9 months after surgery. Two patients after non-radical surgery live without progression within 14 and 9 months after removal of G1 and G3 liposarcoma, respectively. In all patients who underwent vascular prosthetics, their patency is fully preserved. Long-term results suggest that even with the non-radical nature of surgery, a long period without recurrence is possible.

Expanding the scope of operations for extraperitoneal tumors, including pelvic localization, remains a matter of debate. In our small group of patients, resection of the iliac vessels in patients with liposar- 
comas and schwannomas can be considered justified, given the good immediate and long-term results.

\section{Conclusions}

1. Surgical intervention in the treatment of pelvic inorganic tumors involving the main vessels is the only radical method of treatment
2. Invasion of the main arterial and venous vessels is not a contraindication to surgery in patients with pelvic tumors.

3. Combined angioplastic interventions allow to achieve a long without recurrent period even after cytoreductive operations.

\section{LITERATURE}

1. Cherkes VL. Diagnostika neorgannykh zabriushinnykh opukholeǐ [Diagnosis of extraorganic retroperitoneal tumors]. Vestn Akad Med Nauk SSSR. 1968;23(6):44-8. Russian. PMID: 5746009.

2. Rotte KH, Mateev B, Wirbatz W. Zur Diagnostik der primдren retroperitonealen Tumoren [Diagnosis of primary retroperitoneal tumors]. Dtsch Gesundheitsw. 1970 Dec 17;25(51):2397-405. German. PMID: 4925659.

3. Iacobuzio-Donahue CA, Michael C, Baez P, Kappagantula R, Hooper JE, Hollman TJ. Cancer biology as revealed by the research autopsy. Nat Rev Cancer. 2019;19(12):686-697. doi:10.1038/s41568-019-0199-4

4. Zhu P, Fan Z. Cancer stem cells and tumorigenesis. Biophys Rep. 2018;4(4):178-188. doi:10.1007/s41048-018-0062-2

5. Bulletin of the National Cancer Registry of Ukraine. Kyiv. 2021; Vol. 22

6. Mota MMDS, Bezerra ROF, Garcia MRT. Practical approach to primary retroperitoneal masses in adults. Radiol Bras. 2018;51(6):391-400. doi:10.1590/0100-3984.2017.0179

7. Fu F, Ma X, Lu Y, Xu H, Ma R. Clinicopathological Characteristics and Prognostic Prediction in Pseudomyx- oma Peritonei Originating From Mucinous Ovarian Cancer. Front Oncol. 2021;11:641053. Published 2021 Apr 21. doi:10.3389/fonc. 2021.641053

8. Mikuła-Pietrasik J, Uruski P, Tykarski A, Książek K. The peritoneal "soil" for a cancerous "seed": a comprehensive review of the pathogenesis of intraperitoneal cancer metastases. Cell Mol Life Sci. 2018;75(3):509-525. doi:10.1007/ s00018-017-2663-1

9. Chew MH, Yeh YT, Toh EL, et al. Critical evaluation of contemporary management in a new Pelvic Exenteration Unit: The first 25 consecutive cases. World J Gastrointest Oncol. 2017;9(5):218-227. doi:10.4251/wjgo.v9.i5.218

10. Brown KG, Koh CE, Solomon MJ, Qasabian R, Robinson D, Dubenec S. Outcomes After En Bloc Iliac Vessel Excision and Reconstruction During Pelvic Exenteration. Dis Colon Rectum. 2015;58(9):850-856. doi:10.1097/ DCR.0000000000000421

11. Lau YC, Brown KGM, Lee P. Pelvic exenteration for locally advanced and recurrent rectal cancer-how much more? J Gastrointest Oncol. 2019;10(6):1207-1214. doi:10.21037/ jgo.2019.01.21
ХІРУРГІЧНЕ

ЛІКУВАННЯ ХВОРИХ

ІЗ ПОЗАОРГАННИМИ

НОВОУТВОРЕННЯМИ

ТАЗОВОЇ ЛОКАЛІЗАЦЇ̈

3 ІНВАЗІЕЮ КЛУБОВИХ

СУДИН

I. В. Криворотько,

А. В. Чикін, М. С. Тимченко,

С. О. Береснєв,

T. 3. Александров
Анотація. Метою нашого дослідження було визначення показань до розширення обсягу операцій у хворих з тазовими позаорганними локальними утвореннями.

Матеріали та методи. Наведено результати хірургічного лікування 7 хворих з неорганними пухлинами тазової локалізації, яким була виконана резекція магістральних судин у зв'язку з їх залученням до пухлинного процесу.

Результати і обговорення. Усього на клубових артеріях виконано 7 втручань -2 резекції $з$ анастомозом «кінець в кінець» та 5 протезів (один випадок - резекція аорти з реконструкцією біфуркаційним протезом). Пацієнти з тазовими екстраорганними пухлинами є особливою когортою пацієнтів через наявність кількох органів у вузькому просторі, що неминуче змушує їх щільно прилягати до пухлини.

Місцеворозповсюджений пухлинний процес при екстраорганних пухлинах із залученням магістральних судин малого таза та прилеглих органів не є підставою для відмови від операції, i, незважаючи на ускладнення, повторні рецидиви та попередні операції, добре переноситься пацієнтами. Це особливо важливо через відсутність реальної альтернативи хірургічному лікуванню цієї групи пацієнтів.

Висновки. Хірургічне втручання при лікуванні неорганічних пухлин малого таза з ураженням магістральних судин є єдиним радикальним методом лікування. Інвазія магістральних артеріальних і венозних судин не є протипоказанням до операції у хворих з пухлинами малого таза. Комбіновані ангіопластичні втручання дозволяють досягти тривалого безрецидивного періоду навіть після циторедуктивних операцій.

Ключові слова: позаорганні пухлини таза, судини, хірургічне лікування. 